\title{
FAKTOR KEJADIAN IN-STENT RE-STENOSIS PADA PASIEN PENYAKIT JANTUNG KORONER
}

\author{
Devi Susanti $^{1^{*}}$, Elly Nurachmah ${ }^{2}$, Tuti Herawati ${ }^{3}$ \\ 1. Program Studi DIII Keperawatan, STIKes Mitra Keluarga, Bekasi-Indonesia \\ 2. Departemen Keperawatan Medikal Bedah, Universitas Indonesia, Depok-Indonesia \\ 3. Departemen Keperawatan Medikal Bedah, Universitas Indonesia, Depok-Indonesia \\ *Korespondensi: Devi Susanti | STIKes Mitra Keluarga | devisusanti86@yahoo.com
}

\begin{abstract}
Abstrak
Pendahuluan: Penyakit Jantung Koroner adalah penyakit yang diakibatkan penyempitan pembuluh darah koroner akibat aterosklerosis. Salah satu penatalaksanaan Penyakit Jantung Koroner adalah pemasangan stent untuk mengatasi sumbatan pada pembuluh darah jantung. Tindakan tersebut dapat berulang apabila terjadi sumbatan pada lokasi pembuluh darah yang terpasang stent atau disebut in-stent re-stenosis. Penelitian ini bertujuan untuk mengidentifikasi faktor - faktor yang berhubungan dengan tindakan PCI berulang.

Metode: Desain penelitian menggunakan desain non eksperimental jenis cross sectional analitik. Responden sebanyak 70 orang, diperoleh melalui teknik consecutive sampling. Analisis data dilakukan secara univariat, bivariat (chi square dan uji t tidak berpasangan) serta multivariat (regresi logistik berganda).

Hasil: Hasil penelitian menunjukkan bahwa riwayat merokok memiliki hubungan yang signifikan dan merupakan faktor dominan dengan tindakan PCI berulang.

Kesimpulan: Implikasi hasil penelitian dalam keperawatan peningkatan peran perawat sebagai pendidik dalam memberikan pendidikan kesehatan tentang in-stent re-stenosis khususnya pengendalian faktor risiko khususnya kebiasaan merokok pada pasien yang terpasang stent dalam mencegah re-stenosis.
\end{abstract}

Kata Kunci : Stent, In-Stent Re-stenosis, PCI berulang, Penyakit Jantung Koroner.

Diterima 23 November 2018; Accepted 30 Desember 2018

\section{PENDAHULUAN}

Penyakit jantung koroner (PJK) merupakan penyakit kardiovaskuler yang diakibatkan penyempitan pembuluh darah koroner yang disebabkan oleh plak aterosklerosis ataupun spasme (Majid, 2007). Prevalensi kejadian kesakitan dan kematian akibat PJK cukup tinggi. Percutaneous Coronary Intervention (PCI) merupakan tindakan yang paling sering digunakan dalam intervensi revaskularisasi pada pasien PJK. PCI dengan stent merupakan suatu tindakan invasive yang dapat mengurangi risiko penutupan kembali sebagian ataupun total pembuluh darah secara tiba - tiba akibat tindakan PTCA atau disebut re-stenosis (Smeltzer, S. C., \& Bare, B, 2008). Penyelidikan Benesten dan Stress (2003) (dalam Stone, et.al, 2009) membuktikan bahwa penggunaan stent lebih baik dibandingkan PTCA dalam kaitannya dengan re-stenosis. Dua jenis utama stent yang dapat digunakan antara yaitu Bare Metal Stent (BMS) dan Drug Elluting Stent (DES) (Hartree, 2013).

Tindakan PCI dengan stent merupakan tindakan yang hanya mengatasi kurangnya suplai darah ke otot jantung, sehingga pasien setelah PCI akan tetap berisiko mengalami perkembangan PJK lebih lanjut karena ada faktor risiko PJK yang sebelumnya telah dimiliki. Pasien PJK yang telah dilakukan PCI dengan stent dapat mengalami serangan jantung berulang karena terjadi re-stenosis yang disebut in stent re-stenosis. Restenosis merupakan penyempitan kembali pembuluh darah yang menyebabkan penurunan aliran darah koroner setelah prosedur intravascular (Kraitzer, Kloog, \& Zilberman, 2007). Hal ini menyebabkan pasien membutuhkan tindakan revaskularisasi koroner atau PCI berulang. Risiko re-stenosis paling besar terjadi selama 6 bulan pertama setelah PCI. Sekitar 50\% pasien mengalami re-stenosis setelah stenting, sehingga harus mengulang Target Vessel Revascularization (TVR) atau PCI berulang.

Tindakan PCI berulang juga menunjukan data yang signifikan di Indonesia. Menurut sumber rekam medis RS jantung RS Jantung dan Pembuluh Darah Harapan Kita yang merupakan RS rujukan nasional menunjukkan sekitar $80 \%$ pasien yang menjalani PCI berulang akibat pola hidup yang tidak sehat seperti ketidakpatuhan akan diet, merokok dan stress. Sementara menurut data rekam medis RS Mitra Keluarga Bekasi Timur tahun 2014 menunjukkan sekitar 190 pasien $(39,7 \%)$ dari 478 pasien yang dilakukan tindakan PCI dengan stent di ruang kateterisasi jantung dan 30 pasien $(15,8 \%)$ diantaranya dilakukan 
tindakan PCI berulang.

Faktor - faktor yang menyebabkan re-stenosis adalah jenis kelamin, usia, durasi PCI sebelumnya, jenis stent, riwayat DM, riwayat merokok, serta manajemen diri setelah PCI sebelumnya. Manajemen diri pasien PJK setelah PCI meliputi pasien mengikuti program rehabilitasi jantung; melakukan perubahan pola hidup untuk mengurangi faktor risiko PJK seperti berhenti merokok, mengurangi kadar kolesterol, mengikuti diit yang dianjukan dokter, mengurangi berat badan apabila obesitas; mengkonsumsi obat - obat yang dianjurkan oleh dokter seperti obat untuk mengendalikan tekanan darah, kolesterol, aspirin dan clopidogrel untuk mencegah pembekuan darah (Smeltzer, S. C., \& Bare, B, 2010).

Tindakan PCI yang dilakukan lebih dari satu kali akan menimbulkan dampak pada berbagai aspek seperti fisik, psikologis, sosial dan ekonomi. Aspek fisik akan terganggu karena proses angiografi berulang dapat menimbulkan refractory angina. Pasien PJK yang akan menjalani angiografi dan PCI akan mengalami kecemasan. Biaya pasien yang akan dilakukan pemasangan stent di RSMK Mitra Keluarga Bekasi Timur berkisar Rp.55.000.000 sampai dengan Rp.75.000.000. Hal ini belum termasuk biaya perawatan selama pasien di ICCU dan perawatan serta pengobatan setelah dari Rumah Sakit.

Berbagai dampak yang diuraikan diatas dapat dihindari apabila pasien setelah PCI mampu melakukan adaptasi dengan kondisi dan situasinya. Pasien PJK setelah PCI dengan stent diharapkan mampu menerapkan manajemen diri yang optimal dalam aktivitas, stress, pengobatan, maupun diet untuk dapat memperoleh kualitas hidup yang baik dengan pola hidup yang sehat. Apabila kejadian re-stenosis dapat dikendalikan maka dapat meminimalkan terjadinya re-hospitalisasi dan beban re-hospitalisasi akibat tindakan PCI berulang yang harus ditanggung oleh pasien dengan re-stenosis. Oleh karena itu, perlu kajian peneliti merumuskan pertanyaan penelitian apa sajakah faktor - faktor yang berhubungan dengan tindakan PCI berulang pada pasien PJK di RS Mitra Keluarga Bekasi Timur. Penelitian ini bertujuan untuk mengetahui faktor - faktor yang berhubungan dengan tindakan PCI berulang pada pasien PJK.

\section{METODE}

Desain penelitian menggunakan desain non eksperimental jenis cross sectional analitik. Responden sebanyak 70 orang, diperoleh melalui teknik consecutive sampling. Analisis data dilakukan secara univariat, bivariat (chi square dan uji t tidak berpasangan) serta multivariat (regresi logistik berganda). Jenis data yang dikumpulan adalah data primer (hasil angiografi) dan sekunder (kuesioner).

\section{HASIL}

\section{Hasil univariat}

Sebagian besar responden berjenis kelamin laki - laki sebanyak 59 orang $(84,3 \%)$ daripada perempuan. Riwayat merokok responden sebagian besar tidak merokok sebanyak 43 orang $(61,4 \%)$ dibandingkan merokok. Sebagian besar responden tidak mengalami DM sebanyak 37 orang $(52,9 \%)$ daripada DM. Sebagian besar responden menggunakan jenis stent DES sebanyak 56 orang $(84,3 \%)$ daripada jenis stent BMS. Durasi PCI sebelumnya sebagian besar responden lebih dari enam bulan sebanyak 59 orang $(81,4 \%)$ daripada kurang dari enam bulan. Sebagian besar responden yang menjalani tindakan PCI berulang tidak mengalami re-stenosis sebanyak 57 orang $(81,4 \%)$ daripada pasien yang mengalami re-stenosis. Rata - rata usia responden 54,10 tahun (SD 7,712; CI 52,26-55,94), dengan umur termuda adalah 42 tahun dan tertua berusia 79 tahun. Skor rata - rata kemampuan manajemen diri responden adalah 68,63 (SD 10,895; CI 66,03-71,23), dengan skor tertinggi adalah 88 dan terendah adalah 44.

Tabel 1. Uji normalitas usia dan manajemen diri responden di RS Mitra Keluarga Bekasi Timur Bulan Juni $2015(\mathrm{n}=70)$

\begin{tabular}{ccc}
\hline No & Variabel & P value \\
\hline 1. & Usia & 0,053 \\
\hline 2. & Manajemen diri & 0,000 \\
\hline
\end{tabular}

Hasil uji normalitas tabel 5.3 di atas menunjukkan bahwa variabel usia berdistribusi normal sehingga menggunakan uji non parametrik jenis uji t tidak berpasangan. Sementara variabel manajemen diri tidak berdistribusi normal sehingga menggunakan uji non parametrik Mann-Whitney. 


\section{Hasil Bivariat}

Hasil analisis menunjukkan bahwa rata - rata perbedaan usia sebesar 1,067 dengan nilai CI 95\% ($3,690-5,825)$. Hasil uji statistik menggunakan uji t tidak berpasangan didapatkan $p$ value $=0,656$ pada $\alpha=$ 0,05 , kesimpulan uji Ho gagal tolak yang berarti bahwa tidak ada hubungan antara usia dengan tindakan PCI berulang pada pasien PJK.

Hasil analisis hubungan antara jenis kelamin dengan tindakan PCI berulang pada pasien PJK didapatkan bahwa sebagian besar responden yang telah menjalani tindakan PCI berulang berjenis kelamin laki - laki tidak mengalami re-stenosis. Sementara seluruh responden yang berjenis kelamin perempuan tidak mengalami re-stenosis. Hasil uji statistik didapatkan nilai $p$ value $=0,111$ berarti dapat disimpulkan tidak ada hubungan yang signifikan antara jenis kelamin dengan tindakan PCI berulang.

Hasil analisis hubungan antara jenis stent dengan tindakan PCI berulang pada pasien PJK didapatkan bahwa sebagian besar responden yang menggunakan jenis stent DES dan lainnya yang menggunakan jenis stent BMS juga tidak mengalami re-stenosis. Hasil uji statistik didapatkan nilai $p$ value $=0,715$ berarti dapati disimpulkan tidak ada hubungan yang signifikan antara jenis stent dengan tindakan PCI berulang.

Hasil analisis hubungan antara durasi PCI dengan tindakan PCI berulang pada pasien PJK didapatkan bahwa responden dengan durasi PCI $<6$ bulan tidak mengalami re-stenosis. Sementara responden dengan durasi $\geq 6$ bulan lebih banyak mengalami re-stenosis. Hasil uji statistik didapatkan nilai $p$ value $=0,676$ berarti dapat disimpulkan tidak ada hubungan yang signifikan antara durasi PCI dengan tindakan PCI berulang.

Hasil analisis hubungan antara riwayat merokok dengan tindakan PCI berulang pada pasien PJK didapatkan bahwa responden yang telah menjalani tindakan PCI berulang dengan tidak merokok lebih banyak mengalami tidak re-stenosis. Sementara responden dengan riwayat merokok sedikit yang mengalami re-stenosis. Hasil uji statistik didapatkan nilai $p$ value $=0,002$ berarti dapat disimpulkan terdapat hubungan yang signifikan antara riwayat merokok dengan tindakan PCI berulang. Selain itu diperoleh pula nilai $\mathrm{OR}=7,843$ kali dimana pasien dengan riwayat merokok berpeluang 7,843 kali untuk mengalami re-stenosis dibandingkan dengan pasien yang tidak merokok.

Hasil analisis hubungan antara riwayat DM dengan tindakan PCI berulang pada pasien PJK didapatkan bahwa responden yang telah menjalani tindakan PCI berulang dengan riwayat tidak DM lebih banyak mengalami tidak re-stenosis. Sementara responden dengan riwayat DM lebih banyak tidak mengalami restenosis. Hasil uji statistik didapatkan nilai $p$ value $=0,249$ berarti dapat disimpulkan tidak ada hubungan yang signifikan antara riwayat DM dengan tindakan PCI berulang.

Hasil analisis hubungan antara manajemen diri dengan tindakan PCI berulang pada pasien PJK didapatkan nilai $p$ value $=0,115$ berarti dapat disimpulkan tidak ada hubungan antara manajemen diri dengan tindakan PCI berulang.

\section{Hasil Multivariat}

Dari hasil analisa multivariat menunjukkan bahwa variabel yang berhubungan secara bermakna dengan tindakan PCI berulang pada pasien PJK adalah variabel riwayat merokok. Selain itu, dari hasil analisis diatas didapatkan juga nilai odd rasio (OR) pada riwayat merokok adalah 9,335, yang artinya pasien yang dengan riwayat merokok memiliki peluang terhadap risiko tindakan PCI berulang sebesar 13,157 kali lebih besar dibandingkan pasien yang tidak merokok.

Sementara variabel yang paling besar pengaruhnya terhadap risiko tindakan PCI berulang dapat dilihat dari nilai Exponen B pada variabel yang signifikan. Pada hasil analisis diatas, yang paling besar nilai Exponen B nya adalah riwayat merokok, sehingga dapat diartikan bahwa riwayat merokok merupakan variabel dominan yang paling besar pengaruhnya terhadap risiko terjadinya tindakan PCI berulang pada pasien PJK.

\section{PEMBAHASAN}

Berdasarkan data hasil univariat didapatkan bahwa rata - rata usia responden adalah 54 tahun dengan usia tertua 79 tahun dan termuda 42 tahun. Hasil ini menunjukkan terdapat rentang usia yang cukup signifikan pada pasien PJK. Menurut Wu (2007), risiko penyakit jantung koroner meningkat pada usia diatas 55 tahun pada laki-laki dan diatas 65 tahun pada perempuan. Hal ini sesuai dengan hasil penelitian 
dimana rata- rata pasien PJK yang berusia 54 tahun berjenis kelamin laki - laki dan pasien yang berusia 79 tahun yang merupakan usia tertua dalam penelitian berjenis kelamin perempuan. Selain itu, hasil penelitian Turk et al., (2008) menjelaskan In Stent Re-stenosis (ISR) lebih banyak terjadi pada usia $\leq 55$ tahun (odd rasio 2,6 ; $95 \% \mathrm{CI}, 1,03-6,5)$.

Hasil analisis univariat menggambarkan jenis kelamin laki - laki lebih banyak daripada perempuan, sedangkan hasil bivariat menunjukkan bahwa tidak ada hubungan antara jenis kelamin dengan tindakan PCI berulang. Hal ini didukung pula dengan hasil multivariat yang menjelaskan bahwa jenis kelamin bukan merupakan faktor yang menyebabkan tindakan PCI berulang. Hasil penelitian tidak sesuai dengan penelitian Onuma et al., (2009) yang menyatakan bahwa ada hubungan yang bermakna antara laki - laki yang terpasang stent DES dengan BMS terhadap kejadian re-stenosis $(2,6 \%$ vs $1,5 \%, \mathrm{p}=0,04)$ dan tidak ada hubungan yang signifikan perempuan yang terpasang stent DES dengan BMS $(2,0 \%$ vs $1,8 \%, \mathrm{p}=$ $0,52)$.

Jenis stent yang digunakan oleh pasien PJK pada penelitian ini menurut hasil analisis univariat menunjukkan bahwa sebagian besar menggunakan stent jenis DES. Hasil analisis bivariat didapatkan bahwa tidak ada hubungan jenis stent dengan tindakan PCI berulang pada pasien PJK. Hasil menunjukkan baik penggunaan jenis stent DES maupun BMS memiliki prosentase kecil mengalami re-stenosis.

Hasil penelitian ini tidak sejalan dengan penelitian yang dilakukan oleh Stone et al. (2009) yang melakukan suatu studi dengan randomisasi membandingkan antara pasien yang mendapat Paclitaxel Eluting Stent (PES) dengan Bare Metal Stent (BMS) pada PCI, dimana pasien dengan PES secara signifikan lebih sedikit kejadian revaskularisasi ulang. Dalam kedua kelompok pasien, tingkat restenosis adalah nyata dan signifikan ( $\mathrm{P}=0,00001)$ lebih tinggi dengan stent bare-metal dibandingkan dengan DES, dengan OR 6,33 $(4,57-8,76)$ pada populasi nondiabetes dan $5.27(3,36-8,28)$ di diabetes populasi. Selain itu, hasil analisis multivariat Pfisterer et al (2006) menyatakan bahwa DES merupakan faktor dominan menurunkan risiko re-stenosis terkait target vessel revascularization (TVR) (HR 0,52, 95\% CI 0,33-0,85, p 0,009).

Hasil analisis univariat durasi PCI menunjukkan sebagian besar pasien PJK mengalami tindakan PCI kembali setelah enam bulan berikutnya. Hasil analisis bivariat menjelaskan bahwa tidak ada hubungan antara durasi PCI dengan tindakan PCI berulang. Re-stenosis stent merupakan komplikasi yang jarang terjadi namun mengancam jiwa. Re-stenosis stent dapat diklasifikasikan menurut lama waktu implantasi stent dipasang yaitu trombosis stent akut terjadi dalam waktu 24 jam dari prosedur; stent trombosis subakut antara 1 sampai dengan 30 hari setelah implantasi; stent trombosis terlambat (late stent thrombosis) antara 1 bulan dan 1 tahun setelah implantasi; dan sangat terlambat stent trombosis (very late stent thrombosis) lebih dari 1 tahun setelah prosedur (Herman \& Barthwal, 2008). Oleh karena itu dapat dsimpulkan bahwa kejadian re-stenosis pada hasil penelitian ini menunjukkan late stent thrombosis dan very late thrombosis dimana durasi PCI sebelumnya adalah $>6$ bulan. Durasi PCI dengan terjadinya tindakan PCI berulang yang dalam hal ini terjadinya re-stenosis, mungkin dapat disebabkan dari lama waktu penggunaan obat antiplatelet yang diberikan setelah pemasangan stent baik DES maupun BMS. Lamanya pengobatan clopidogrel tergantung pada pengaturan klinis, tetapi rekomendasi saat ini biasanya untuk BMS, clopidogrel diberikan selama satu bulan, sedangkan untuk DES, clopidogrel untuk setidaknya 12 bulan. Beberapa ahli jantung merasa bahwa clopidogrel harus dilanjutkan tanpa batas (Hartree, 2013).

Gambaran riwayat merokok pada pasien PJK dalam penelitian ini menunjukkan bahwa sebagian besar pasien tidak memiliki riwayat merokok. Hasil bivariat menggambarkan terdapat hubungan yang signifikan antara riwayat merokok dengan tindakan PCI berulang. Riwayat merokok merupakan faktor dominan yang berhubungan dengan tindakan PCI berulang menurut hasil multivariat dalam penelitian ini.

Woods. et al. (2005) mengatakan perokok memiliki risiko dua kali menderita miokard infark daripada yang tidak merokok. Perokok memiliki risiko peningkatan agregasi trombosit serta perkembangan aterosklerotik lebih cepat, sehingga dapat menyebabkan trombosis koroner. Cohen et al, (2001) melakukan penelitian mengenai hubungan perokok dengan re-stenosis didapatkan tidak ada perbedaan dalam tingkat re-stenosis klinis dan angiografi, hal ini dikarenakan kurangnya kepekaan terhadap stenosis dan keengganan perokok untuk mencari bantuan medis meskipun angina berulang. Pada pasien yang menjalani PCI, merokok berhubungan dengan rendahnya target lesion revoscularization (TLR) tanpa mempengaruhi re-stenosis angiografi. Target lesi revaskularisasi (TLR) terjadi pada 6,6\% dari perokok dan 10,1\% dari 
bukan perokok $(\mathrm{P}<0,001)$. Tingkat TLR tetap secara signifikan lebih rendah pada perokok dengan risiko relatif sebesar 0,69 (95\% CI, 0,54-0,88).

Hasil analisis hubungan antara riwayat DM dengan tindakan PCI berulang pada pasien PJK didapatkan bahwa responden yang telah menjalani tindakan PCI berulang dengan riwayat tidak DM lebih banyak mengalami tidak re-stenosis, sedangkan responden dengan riwayat DM lebih banyak mengalami restenosis. Hasil uji statistik menjelaskan tidak ada hubungan yang signifikan antara riwayat DM dengan tindakan PCI berulang.

Hasil penelitian ini tidak sesuai dengan penelitian yang dilakukan oleh Stone et al.(2009) yang menyatakan bahwa pasien dengan diabetes memiliki risiko untuk terjadinya in-stent re-stenosis. Hal ini menunjukkan diabetes mellitus dapat menyebabkan timbulnya re-stenosis pada pasien PJK dengan stent. Meta-analisis dari enam uji klinis menunjukkan bahwa odds rasio (OR) restenosis arteri koroner terkait dengan diabetes adalah 1,61 (95\% CI 1,21-2,14, P 0,004). OR in-stent restenosis pada pasien diabetes dibandingkan dengan subyek kontrol rata-rata 1,94 (95\% CI 1,46-2,58) pada kelompok yang menerima stent bare-metal $(\mathrm{P}<0,00001)$.

Hasil univariat menjelaskan bahwa skor rata - rata manajemen diri pasien dalam penelitian adalah sebesar 68,63 dengan nilai skor terendah 44 dan tertinggi 88. Hasil analisis hubungan antara manajemen diri dengan tindakan PCI berulang pada pasien PJK didapatkan bahwa tidak ada hubungan antara manajemen diri dengan tindakan PCI berulang. Hal ini didukung dari hasil multivariat yang menunjukkan manajemen diri bukan merupakan faktor dominan yang berhubungan dengan tindakan PCI berulang. Rentang skor manajemen diri menunjukkan rentang yang cukup signifikan. Hal ini menggambarkan manajemen diri pasien PJK masih ada belum baik setelah PCI sebelumnya. Walaupun hasil bivariat menjelaskan tidak ada hubungan manajemen diri dengan tindakan PCI berulang, namun hal ini merupakan bagian yang penting dalam penatalaksanaan pasien PJK yang telah dilakukan tindakan PCI. Meskipun terapi pengobatan tekanan darah maupun kolesterol efektif diberikan pada pasien dengan PJK, pendekatan nonfarmakologis juga dapat memilki dampak yang luar biasa dan lebih hemat biaya (Bibbins-Domingo K, Chertow GM, Coxson PG, et al, 2010). Pengobatan glukosa darah efektif dalam mengurangi komplikasi mikrovaskular seperti retinopati dan penyakit ginjal, namun memiliki manfaat pada penyakit PJK sangat minim (Zhang CY, Sun AJ, Zhang SN, et al, 2010), dan pendekatan gaya hidup lebih efektif untuk mencegah diabetes dan terkait faktor risiko PJK. Perilaku sehat dan faktor fisiologis seperti tekanan darah, kolesterol, dan glukosa dapat menentukan masa depan pasien PJK.

\section{KESIMPULAN}

Karakteristik responden PJK yang dilakukan tindakan PCI berulang adalah sebagai berikut:

Usia responden bervariasi antara rentang dewasa muda sampai lanjut usia. Sebagian besar responden berjenis kelamin laki - laki. Mayoritas jenis stent yang digunakan adalah DES. Durasi PCI sebelumnya sebagian besar lebih dari enam bulan. Sebagian besar responden tidak memiliki riwayat DM dan merokok. Skor rata - rata manajemen diri adalah 68,63 dari skor tertinggi manajemen diri yaitu 88. Tidak ada hubungan antara usia, jenis kelamin, jenis stent, durasi PCI, riwayat DM dan manajemen diri dengan tindakan PCI berulang pada pasien PJK. Ada hubungan antara riwayat merokok dengan tindakan PCI berulang pada pasien PJK. Faktor yang paling dominan berhubungan dengan tindakan PCI berulang pada pasien PJK adalah riwayat merokok.

Implikasi hasil penelitian dalam keperawatan adalah peran perawat dalam memberikan discharge planning terkait pencegahan sekunder khususnya program edukasi berhenti merokok pada pasien yang terpasang stent dalam mencegah re-stenosis. Saran bagi peneliti selanjutnya untuk dapat melakukan penelitian lanjutan terkait gambaran kepatuhan pasien PJK setelah tindakan PCI dalam melakukan managemen diri faktor risiko PJK.

\section{UCAPAN TERIMA KASIH}

Ucapan terimakasih kepada Sekolah Tinggi Ilmu Kesehatan Mitra Keluarga dan Rumah sakit Mitra Keluarga Bekasi Timur yang telah memberikan kesempatan kepada penulis untuk melakukan penelitian ini.

\section{REFERENSI}

Bibbins-Domingo K, Chertow GM, Coxson PG, et al. (2010). Projected effect of dietary salt reductions on 
future cardiovascular disease. N Engl J Med 2010;362:590 -9

Cohen, D. J., Doucet, M., Cutlip, D. E., Ho, K. K. L., Popma, J. J., \& Kuntz, R. E. (2001). Impact of Smoking on Clinical and Angiographic Restenosis After Percutaneous Coronary Intervention Another Smoker 's Paradox?

Hartree, D. N. (2013). Percutaneous Coronary Intervention. Retrieved April 12, 2015, from http://patient.co.uk/doctor.percutaneous-coronary-intervention

Herman, BA \& Barthwal R. (2008). Very late stent thrombosis after discontinuation of clopidogrel therapy Rohit Barthwal and Brian A Herman. (MJA 2008; 189: 229-230. Volume 189 Number 4 (18 August 2008). Diakses dari https://www.mja.com.au/system/files/issues/189_04_180808/bar10427_fm.pdf pada tanggal 26 Juni 2015

Kraitzer, A., Kloog, Y., \& Zilberman, M. (2007). Approaches for Prevention of Restenosis, 1(c), 583-603. http://doi.org/10.1002/jbm.b.30974

Majid, A., \& Utara, U. (2008). Penyakit Jantung Koroner : Patofisiologi, Pencegahan, dan Pengobatan Terkini. Jurnal USUe-repository.

Onuma, Y., Kukreja, N., Daemen, J., Garcia-Garcia, H. M., Gonzalo, N., Cheng, J. M., ... Serruys, P. W. (2009). Impact of Sex on 3-Year Outcome After Percutaneous Coronary Intervention Using Bare-Metal and Drug-Eluting Stents in Previously Untreated Coronary Artery Disease. Insights From the RESEARCH (Rapamycin-Eluting Stent Evaluated at Rotterdam Cardiology Hospit. JACC: Cardiovascular Interventions, 2(7), 603-610. http://doi.org/10.1016/j.jcin.2009.03.016

Pfisterer, M., Brunner-La Rocca, H. P., Buser, P. T., Rickenbacher, P., Hunziker, P., Mueller, C., Kaiser, C. (2006). Late Clinical Events After Clopidogrel Discontinuation May Limit the Benefit of Drug-Eluting Stents. An Observational Study of Drug-Eluting Versus Bare-Metal Stents. Journal of the American College of Cardiology, 48(12), 2584-2591. http://doi.org/10.1016/j.jacc.2006.10.026

Smeltzer, S. C., \& Bare, B. (2008). Text Book of Medical Surgical Nursing. $11^{\text {th }}$ ed. Philadelphia: Lippincott.

Smeltzer, S. C., \& Bare, B. (2010). Text Book of Medical Surgical Nursing. $12^{\text {th }}$ ed. Philadelphia: Lippincott.

Stone, G., Lansky, A., Pocock, S., Gersh, B., Dangas, G., \& Wong, S. (2009). Paclitaxel-Eluting Stents Compared With Bare Metal Stents in Diabetic Patients With Acute Miocardial Infarction: The harmonizing outcomes with revascularization and stent in acute myocardial infarction (HORIZONSAMI) trial. Circ Cardiovasc Intev, 2011(4), 130-138.

Turk, a. S., Levy, E. I., Albuquerque, F. C., Pride, G. L., Woo, H., Welch, B. G., ... Fiorella, D. J. (2008). Influence of patient age and stenosis location on wingspan in-stent restenosis. American Journal of Neuroradiology, 29(1), 23-27. http://doi.org/10.3174/ajnr.A0869

Woods, S., Froelicher, E., Motzer, S., \& Bridges, E. (2005). Cardiac Nursing (5th ed.). Philadelphia: Lippincott Williams \& Wilkins.

Wu, L. (2007). Knowledge, Perceived Risk and Preventive Behavior of Coronary Heart disease in Chinese Hong Kong Women. Proquest Dissertations and Theses.Retrieved March 20, 2015, from http://search.proquest.com/docview/304879562?accountid=17242.

Zhang CY, Sun AJ, Zhang SN, et al. (2010). Effects of intensive glucose control on incidence of cardiovascular events in patients with type 2 diabetes: a meta-analysis. Ann Med 2010;42:305-15 